UDC 339.12

JEL Classification: C23, C31, D73, 047

http://doi.org/10.21272/mmi.2019.3-28

Tatyana Milova,

Ph.D., Volodymyr Vynnychenko Central Ukrainian State Pedagogical University, Ukraine

Kateryna Troshkina,

Ph.D., Volodymyr Vynnychenko Central Ukrainian State Pedagogical University, Ukraine

Yevhenii Horlov,

Ph.D., Scholarship Program of the Government of the Republic of Poland for Young Academicians, Poland

Jaroslaw Dobkowski,

Dr.Sc., Professor, University of Warmia and Mazury in Olsztyn, Poland

\title{
COUNTRY'S BRAND AND CORRUPTION LEVEL: COINTEGRATION ANALYSIS
}

Abstract. The paper summarized the arguments and counterarguments in the scientific debate on the impact of corruption on a country's brand. The modern approaches to the analysis of corruption's impact on the country's macroeconomic indicators were analysed. The authors justified that increasing the corruption's level is considered as one of the most significant deterrents to the radical political and economic changes taking place in the countries by society. The main purpose of the paper is to analyse the long-term cause-and-effect relationships between Control of Corruption and the country's brand. Four European countries (Latvia, Lithuania, Poland and Ukraine) were selected as the object of the investigation, which pursued an evolutionary policy of reforming the political and economic system after the collapse of the Soviet Union, which encouraged the practice of eliminating corruption. The research period was 2000-2018. With a purpose to check the hypothesis of the investigation the 3-stage algorithm to estimate the long-term cause-and-effect relationships between Control of Corruption and the key parameters of the country brand is developed. The developed algorithm was based on the Augmented Dicker-Fuller test and granger casualty test. It is established that for Ukraine, the interconnections between Control of Corruption and International migrant stock, Control of Corruption and Exports of goods and services, Control of Corruption and Foreign direct investment had a unidirectional character of influence of the corruption's level on the components of the country's brand. The findings proved that $51.73 \%, 43.79 \%$ and $66 \%$ of the total fluctuations of International migrant stock, Exports of goods and services, Foreign direct investment depend on changes in the level of corruption in the country. The obtained results allowed concluding that for the European Union countries (Poland, Lithuania and Latvia) it was the country brand that had a positive impact on reducing the corruption's level. It was justified that the choice of a specific model for combating the corruption's level in the chosen countries significantly determined the course of their political transformation and influenced the change's rate of the social and economic development.

Keywords: brand, stakeholders, competitiveness, investors, corruption.

Introduction. The stretching of the competition at the European market provoke the continuously developing and improving of the countries competitiveness with the purpose to attract the foreign stakeholders for investing into the country's economy. Noted, that the stakeholders make decisions considering the country's economic and political stability. Besides, countries could attract additional financing into the country through the developing of the touristic industry. In this case, the tourist considers the parameters as country's brand.

It should be highlighted, that the developed European countries have the more capacity to attract the new stakeholders, tourists and foreign financing as they have more stable economic and political stability. The worse situation for the latest EU members which have the common history as Soviet Union Countries. Thus, the dynamic of Corruption Perception Index (Figure 1) proved that Latvia, Lithuania and Poland have the huge gap in the score compare with the top 10 countries for 2012-2018 years. Besides, Ukraine has the big gap not only with the leader countries, also compare with the Latvia, Lithuania and Poland.

From the other side, the huge rate of corruption has a negative impact on the country's brand. Consequently, it leads to increasing of the untrusty level to the countries among the stakeholders. In this case, the analysed countries Latvia, Lithuania, Poland and Ukraine as a potential candidate to become

Cite as: Milova, T., Troshkina, K., Horlov, Y. \& Dobkowski, J. (2019). Country's Brand and Corruption Level: Cointegration Analysis. Marketing and Management of Innovations, 
the EU members should orient and synchronise policy on restoring the corruption level and increasing the country's brand as the developed EU countries.

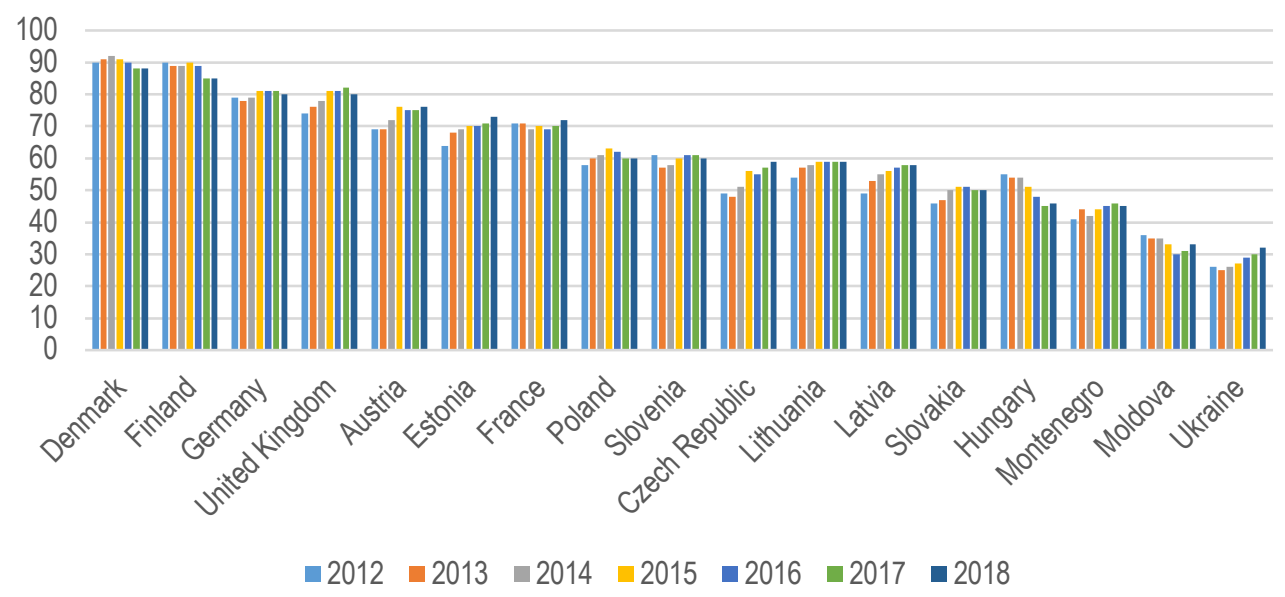

Figure 1. The dynamic of Corruption Perception Index, 2012-2018 years

Source: developed by the authors on the basis (Corruption Perceptions, 2019).

Besides, it's necessary to understand the significance of the relationship between corruption level and the country's brand. Such finding could be used as the orienteers for the first steps to recovering the country's brand and decreasing the corruption level.

Literature Review. The huge range of scientists had investigated the main parameter which influences on the country's brand with a purpose to allocate the main drives for increasing brand's score in the worldwide rating. Thus, the authors in the paper (Andéhn et al., 2016) analysed the country brand through the assessment of the role of product's country-of-origin. They proved that the quality of the product has a statistically significant impact on the country brand and image.

The scientists Herrero-Crespo A., San Martín Gutiérrez H. and Garcia-Salmones M. D. M. investigated the relationship between the country brand and the higher education services. In their investigation (Herrero-Crespo et al., 2016) the statistically significance interrelationships between the country brand and the higher education services on the example of the Spanish universities was proved.

From the other side, the country brand was analysed by the scientists Halkias G., Davvetas V. and Diamantopoulos A. They allocated the stereotypes and perceived brand global and local level as the drivers of the country brand (Halkias et al., 2016).

The authors in the papers (Bilan et al, 2019; Lyulyov et al, 2018) allocated the macroeconomic stability as a key driver of increasing the brand score of the country. For that purpose, in the investigations (Bilan et al, 2019; Lyulyov et al, 2018) the scientists used Fetscherin model.

Lin C. P. and Chuang C. M. (2016) proved that companies in the country with huge level of corruption generate the value of brand less than companies in the country with the lowest level of corruption. In the paper (Lin and Chuang, 2016) they supposed that country bran could be estimated by the value of companies' brand which operating in the country. For the analysis, they used the Poisson regression model. Ravi S. P. (2015) analysed the relationship between corruption and foreign direct investment. In that case, Ravi supposed that a country with a strong brand had the lowest level of corruption and better capacity to increase foreign direct investment. 
Patrick H. P. (2016) on the example of Caribbean investigated the impact of Corruption on Good Governance. In the investigation, Patrick H. P. (2016) proved the correlation between Corruption on Good Governance.

Thus, the huge range of investigations has already done in the spheres of country brand drivers of different point of view. Besides, the scientist analysed the impact of corruption on the country brand. At the same time, the existing analyses did not consider the cointegration between country's brand parameters and level of corruption.

In this case, the main hypothesises of the paper are:

$\mathrm{H} 1$ : cointegration between country brand parameters and corruption exists;

$\mathrm{H} 2$ : cointegration between country brand parameters and corruption does not exist.

Methodology and research methods. Based on the findings of the scientists in the paper (Bilan et al, 2019; Lyulyov et al, 2018; Fetscherin, 2010) the impact of corruption on the country's brand could be described using the econometric model as follows:

$$
Y_{i t}=\alpha_{i 0}+\alpha_{i 1} \operatorname{Corr}_{t}+\varepsilon_{t}
$$

where $Y_{i t}$ - country's brand parameters; i=1...n - quantity of country's brand parameters; Corr corruption lev el; $\varepsilon_{t}-$ errors; $\alpha_{0}-$ const.

Thus, accordingly to (Bilan et al, 2019; Lyulyov et al, 2018; Fetscherin, 2010) the main parameters of country's brand are the volume of export $(E)$, tourists $(T)$, foreign direct investment $(F)$. Considering abovementioned the econometric model (1) could be modified and presents as equitation' system:

$$
\left\{\begin{array}{l}
T_{t}=\gamma_{0}+\gamma_{1} \operatorname{Corr}_{t}+\varepsilon_{t} \\
F_{t}=\delta_{0}+\delta_{1} \operatorname{Corr}_{t}+\varepsilon_{t} \\
E_{t}=\beta_{0}+\beta_{1} \operatorname{Corr}_{t}+\varepsilon_{t}
\end{array}\right.
$$

where $\beta_{0}, \gamma_{0}, \delta_{0}, \vartheta_{0}$-const; $\beta_{1}, \gamma_{1}, \delta_{1}, \vartheta_{1}$ - estimated parameters of the econometric model.

The assessment of the parameters $\beta_{1}, \gamma_{1}, \delta_{1}, \vartheta_{1}$ of the econometric model (2) should be realized at the following stages:

Stage 1. Checking the stationarity of the parameters E, T, F, M, Corr in the econometric model (2) using the test of the Augmented Dickey-Fuller (ADF) (Levin et al, 2002):

$$
\Delta Y_{i t}=\zeta+\eta t+\theta Y_{i t-1}+\varphi_{i 1} \Delta Y_{i t-1}+\cdots \varphi_{i p-1} \Delta Y_{i t-p+1}+\varepsilon_{t}
$$

where $\zeta$ - constant, $\eta$ - coefficient on a time trend, $p$ - the lag order of the autoregressive process.

According to the requirements of the Augmented Dickey-Fuller test, the null hypothesis could be rejected if $\theta=0$ and no unit root is present.

Stage 2. At this stage, using the Granger-causality tests (Granger, 1969) the checking of causality between the analysed time series of variables E, T, F and Corr were done. Accordingly, to the Grangercausality tests the unit rest test for the assessment of the autoregression model should be done:

$$
Y_{i t}=\alpha_{1} Y_{i t-1}+\alpha_{2} Y_{i t-2}+\cdots+\alpha_{\mathrm{p}} Y_{i t-\mathrm{p}}+\beta_{1} \operatorname{Corr}_{t-1}+\beta_{2} \operatorname{Corr}_{t-2}+\cdots \beta_{p} \operatorname{Corr}_{t-p}+\varepsilon_{t}(4)
$$




$$
\operatorname{Corr}_{t}=\mu_{1} \operatorname{Corr}_{t-1}+\mu_{2} \operatorname{Corr}_{t-2}+\cdots \mu_{p} \operatorname{Corr}_{t-p}+\gamma_{1} Y_{i t-1}+\gamma_{2} Y_{i t-2}+\cdots+\gamma_{\mathrm{p}} Y_{i t-\mathrm{p}}+\omega_{t}(5)
$$

where $p$ - magnitude of lags, $\alpha$ - the significant of the parameters' country's brand impact, $Y_{i t}$ - the relation between previous and current level, $\mu$ - relation between previous and current significance of corruption level, $\beta$ - significance of corruption level impact on the country's brand parameters, $\gamma-$ significance of country's brand impact on the corruption level.

According to the requirements of the Granger-causality tests the null hypothesis $\beta_{1}=\beta_{2}=\ldots=\beta_{\mathrm{p}}=0$ and $\gamma_{1}=\gamma_{2}=\ldots=\gamma_{\mathrm{p}}=0$ proved the non-existing of causality on the Granger at $Y_{i}$ and vice versa.

Stage 3. At the last stage, the cause-effect relationship between corruption level and country's brand parameters was checked by using the Error Correction model.

Results. For the investigation four countries (Latvia, Lithuania, Poland and Ukraine) was chosen. These countries provided the evolution policy of political and economic reforms after the Soviet Union breaking which focused on the decreasing of the corruption level in the countries. The period of investigation was 2000-2018 years. The dataset was obtained from the reports of the World Data Bank and the Corruption Perceptions Index. The features and descriptive statistics of the econometric model (2) were presented in Table 1.

Table 1. The descriptive statistics of the main and explanatory variables of the regression equation

\begin{tabular}{|c|c|c|c|c|}
\hline Variables & Average value & Standard deviation & Minimum value & Maximum value \\
\hline \multicolumn{5}{|c|}{ Ukraine } \\
\hline Corr & -0.9291074 & 0.1272848 & -1.131518 & -0.7218982 \\
\hline E & $5.59 \mathrm{e}+10$ & $1.84 \mathrm{e}+10$ & $2.21 \mathrm{e}+10$ & $8.39 \mathrm{e}+10$ \\
\hline T & $3.68 \mathrm{e}+09$ & $1.83 \mathrm{e}+09$ & $1.00 \mathrm{e}+09$ & $6.72 \mathrm{e}+09$ \\
\hline F & $4.82 \mathrm{e}+09$ & $3.17 \mathrm{e}+09$ & $6.39 \mathrm{e}+08$ & $1.07 \mathrm{e}+10$ \\
\hline \multicolumn{5}{|c|}{ Lithuania } \\
\hline Corr & .3803876 & .1724269 & .1301493 & .7138361 \\
\hline E & $2.59 \mathrm{e}+10$ & $1.18 \mathrm{e}+10$ & $6.76 \mathrm{e}+09$ & $4.38 \mathrm{e}+10$ \\
\hline T & $1.16 \mathrm{e}+09$ & $3.00 \mathrm{e}+08$ & $5.56 \mathrm{e}+08$ & $1.60 \mathrm{e}+09$ \\
\hline F & $9.99 \mathrm{e}+08$ & $6.26 \mathrm{e}+08$ & $1.80 \mathrm{e}+07$ & $2.29 \mathrm{e}+09$ \\
\hline \multicolumn{5}{|c|}{ Latvia } \\
\hline Corr & .313499 & .1216299 & .0167397 & .5358248 \\
\hline E & $1.31 \mathrm{e}+10$ & $5.50 \mathrm{e}+09$ & $3.49 \mathrm{e}+09$ & $1.05 \mathrm{e}+10$ \\
\hline T & $8.21 \mathrm{e}+08$ & $3.80 \mathrm{e}+08$ & $2.01 \mathrm{e}+08$ & $2.71 \mathrm{e}+09$ \\
\hline F & $8.99 \mathrm{e}+08$ & $6.81 \mathrm{e}+08$ & $-3.24 \mathrm{e}+07$ & .7391052 \\
\hline \multicolumn{7}{|c|}{ Poland } \\
\hline Corr & .4961955 & .1784724 & .1388244 & $3.24 \mathrm{e}+11$ \\
\hline E & $1.89 \mathrm{e}+11$ & $7.76 \mathrm{e}+10$ & $5.71 \mathrm{e}+10$ & $2.57 \mathrm{e}+10$ \\
\hline T & $1.04 \mathrm{e}+10$ & $3.07 \mathrm{e}+09$ \\
\hline F & $1.36 \mathrm{e}+10$ & $6.53 \mathrm{e}+09$ & $4.73 \mathrm{e}+09$ & $7.95 \mathrm{e}+08$ \\
\hline
\end{tabular}

Source: the authors' own calculations based on (World Bank, 2019)

To prove the reliability of findings during the analysis of Control of Corruption impact on the International migrant stock, Exports of goods and services, Foreign direct investment unit root tests were 
employed. The test's findings proved that parameters of the model (2) for all countries were I(1) in first differences (Table 2).

Table 2. Augmented Dickey Fuller Unit Root Test

\begin{tabular}{|l|c|c|c|c|c|}
\hline Series & ADF Test Statistic & $5 \%$ critical values & $10 \%$ critical values & Order & Remarks \\
\hline \multicolumn{7}{|c|}{ Ukraine } \\
\hline Corr & -3.123 & -3.000 & -2.630 & $\mathrm{I}(1)$ & Stationary \\
\hline E & -3.229 & -3.000 & -2.630 & $\mathrm{I}(1)$ & Stationary \\
\hline T & -3.443 & -3.000 & -2.630 & $\mathrm{I}(1)$ & Stationary \\
\hline F & -4.440 & -3.000 & -2.630 & $\mathrm{I}(1)$ & Stationary \\
\hline \multicolumn{7}{|c|}{ Poland } \\
\hline Corr & -5.397 & -3.000 & -2.630 & $\mathrm{I}(1)$ & Stationary \\
\hline E & -3.399 & -3.000 & -2.630 & $\mathrm{I}(1)$ & Stationary \\
\hline T & -3.545 & -3.000 & -2.630 & $\mathrm{I}(1)$ & Stationary \\
\hline F & -5.177 & -3.000 & -2.630 & $\mathrm{I}(1)$ & Stationary \\
\hline \multicolumn{7}{|l|}{ Lithuania } \\
\hline Corr & -2.786 & -3.000 & -2.630 & $\mathrm{I}(1)$ & Stationary \\
\hline E & -3.745 & -3.000 & -2.630 & $\mathrm{I}(1)$ & Stationary \\
\hline T & -3.531 & -3.000 & -2.630 & $\mathrm{I}(1)$ & Stationary \\
\hline F & -5.678 & -3.000 & -2.630 & $\mathrm{I}(1)$ & Stationary \\
\hline \multicolumn{7}{|c|}{ Latvia } \\
\hline Corr & -12.063 & -3.000 & -2.630 & $\mathrm{I}(1)$ & Stationary \\
\hline E & -2.798 & -3.000 & -2.630 & $\mathrm{I}(1)$ & Stationary \\
\hline T & -3.108 & -3.000 & -2.630 & $\mathrm{I}(1)$ & Stationary \\
\hline F & -5.646 & -3.000 & -2.630 & $\mathrm{I}(1)$ & Stationary \\
\hline
\end{tabular}

Source: the authors' own calculations

Findings of the causality analysis were summarized in Tables 3 . According to Table 3 which presents the causal relationships between Control of Corruption and International migrant stock, Control of Corruption and Exports of goods and services, Control of Corruption and Foreign direct investment for all analysed countries had the common one direction impact of the corruption level on the country brand.

Table 3. Findings of the Granger causality test

\begin{tabular}{|c|c|c|}
\hline Null Hypothesis: Obs & F-Statistic & Probability \\
\hline 1 & 2 & 3 \\
\hline \multicolumn{2}{|c|}{ Ukraine } \\
\hline E does not Granger Cause Corr & 4.877 & 0.047 \\
\hline Corr does not Granger Cause E & 22.75 & 0.235 \\
\hline T does not Granger Cause Corr & 25.101 & 0.000 \\
\hline Corr does not Granger Cause T & 4.332 & 0.115 \\
\hline F does not Granger Cause Corr & 13.12 & 0.001 \\
\hline Corr does not Granger Cause F & 2.8588 & 0.239 \\
\hline \multicolumn{2}{|c|}{} & Poland \\
\hline E does not Granger Cause Corr & 1.4671 & 0.480 \\
\hline Corr does not Granger Cause E & 7.4479 & 0.024 \\
\hline T does not Granger Cause Corr & 0.95115 & 0.622 \\
\hline Corr does not Granger Cause T & 6.2201 & 0.045 \\
\hline F does not Granger Cause Corr & 6.4413 & 0.040 \\
\hline Corr does not Granger Cause F & 1.3333 & 0.513 \\
\hline
\end{tabular}


Continued Table 3

\begin{tabular}{|c|c|c|}
\hline 1 & 2 & 3 \\
\hline \multicolumn{2}{|c|}{ Lithuania } \\
\hline E does not Granger Cause Corr & .67865 & 0.712 \\
\hline Corr does not Granger Cause E & 6.9403 & 0.031 \\
\hline T does not Granger Cause Corr & 1.0472 & 0.592 \\
\hline Corr does not Granger Cause T & 9.6704 & 0.008 \\
\hline F does not Granger Cause Corr & 1.8188 & 0.403 \\
\hline Corr does not Granger Cause F & .8064 & 0.668 \\
\hline \multicolumn{2}{|c|}{ Latvia } & 0.597 \\
\hline E does not Granger Cause Corr & 1.0311 & 0.186 \\
\hline Corr does not Granger Cause E & 3.367 & 0.067 \\
\hline T does not Granger Cause Corr & 5.4017 & 0.012 \\
\hline Corr does not Granger Cause T & 8.7752 & 0.000 \\
\hline F does not Granger Cause Corr & 44.434 & 0.036 \\
\hline Corr does not Granger Cause F & 6.6393 & \\
\hline
\end{tabular}

Source: the authors' own calculations

For Ukraine, the paired relationships have F-Statistic as follows: between $E$ and Corr - 4.877), $T$ and Corr - 25.101), F and Corr - 13.12, indicating at the level of $5 \%$ of statistical significance that there is a one-sided causality of the corruption's impact on the indicators $E, T, F$.

At the same time, the changing of $E, T, F$ did not lead to the changing Control of Corruption. For EU countries (Poland, Lithuania and Latvia) the country brand had a positive impact on reducing the level of corruption. In Latvia, there was a bi-directional influx of Control of Corruption and Exports of goods and services. The findings were the similar to the findings obtained in the papers of the scientists Sekrafi $\mathrm{H}$., Sghaier A. (2018), Hakimi, A. and Hamdi H. (2017), Wang Z., Zhang B., Wang B. (2018), Nwankwo (2014).

According to that papers, the countries with the positive upward trend in macroeconomic indicators were exposed to less corruption, and poor countries experienced huge shocks to economic growth than corruption. The choice of a specific model for combating corruption in that countries significantly determined the course of their political transformation and also influenced the pace of change in social and economic development.

In Table 4 the results of using the Error Correction Model were presented. For all countries, Control of Corruption harmed the country's brand. However, only for Ukraine such impact was statistically significant at $5 \%$ level. In that case, the error correction factor was $-1.036812,-0.8395469$ and -2.395702 . It was mean that system recovering the mistakes of the previous period with speed $3 \%, 4 \%$ and $9 \%$ annually. Noted, that all error correction factor was negative and statistically significant which proved the long-term relationship between Control of Corruption on International migrant stock, Exports of goods and services, Foreign direct investment. Besides, R2 proved that $51,73 \%, 43,79 \%$ and $66 \%$ from the total fluctuating of International migrant stock, Exports of goods and services, Foreign direct investment relationship with the corruption. Such findings proved that in Ukraine the corruption had a powerful negative impact on the increase of the country brand and image.

Table 4. The main results of the using the Error Correction Model

\begin{tabular}{|l|c|c|c|}
\hline \multirow{2}{*}{} & $\begin{array}{c}\text { Dependent Variable: } \\
\text { LOG(E) }\end{array}$ & $\begin{array}{c}\text { Dependent Variable: } \\
\text { LOG(F) }\end{array}$ & $\begin{array}{c}\text { Dependent Variable: } \\
\text { LOG(T) }\end{array}$ \\
\cline { 2 - 4 } & 1 & 2 & 3 \\
\hline \multicolumn{4}{|c|}{ Ukraine } \\
\hline $\mathrm{D}(\mathrm{COR})$ & $-.0161033(0.003)$ & $-.3545023(0.005)$ & $-1.516641(0.002)$ \\
\hline
\end{tabular}


Continued Table 4

\begin{tabular}{|l|c|c|c|}
\hline & 1 & 2 & 3 \\
\hline ECM(-1) & $-0.036812(0.006)$ & $-0.0395469(0.014)$ & $-0.095702(0.007)$ \\
\hline$R^{2}$ & 0.5173 & 0.4379 & 0.6601 \\
\hline \multicolumn{5}{|c|}{ Poland } \\
\hline $\mathrm{D}(\mathrm{COR})$ & $-.0442291(0.761)$ & $-.1968655(0.163)$ & $-.1123342(0.501)$ \\
\hline $\mathrm{ECM}(-1)$ & $-.0752118(0.573)$ & $-.1902394(0.197)$ & $-.795666(0.527)$ \\
\hline $\mathrm{R}^{2}$ & 0.1956 & 0.9455 & 0.3910 \\
\hline \multicolumn{5}{|c|}{ Lithuania } \\
\hline $\mathrm{D}(\mathrm{COR})$ & $-.147732(0.426)$ & $-.0112147(0.933)$ & $-1.287225(0.401)$ \\
\hline $\mathrm{ECM}(-1)$ & $.1567738(0.012)$ & $-1.531636(0.006)$ & $-2.369971(0.000)$ \\
\hline $\mathrm{R}^{2}$ & 0.5160 & 0.4870 & 0.7525 \\
\hline \multicolumn{5}{|c|}{ Latvia } \\
\hline $\mathrm{D}(\mathrm{COR})$ & $-.0101233(0.831)$ & $-.1699655(0.092)$ & $-.1939736(0.446)$ \\
\hline $\mathrm{ECM}(-1)$ & $-.1248093(0.011)$ & $-.7997641(0.024)$ & $-1.515712(0.007)$ \\
\hline $\mathrm{R}^{2}$ & 0.6329 & 0.6484 & 0.7610 \\
\hline
\end{tabular}

Source: the authors' own calculations

Conclusions. This study aims at investigating the long-run and causal relationships between Control of Corruption and International migrant stock, Exports of goods and services, Foreign direct investment with the purpose to allocate the most effective model to overcome the problems with the huge level of the corruption. For the analysis, four EU countries were chosen (Latvia, Lithuania, Poland and Ukraine) which provides the political and economic reforms after the Soviet Union had broken down. The period for investigation was 2000-2018. The findings proved the hypothesis that joining the EU (before that the law integration and synchronisation should be realised) had a positive impact on the corruption level in the country. The investigation was done by using the Augmented Dickey-Fuller Unit Root Test, Granger causality test and Error Correction Model. The empirical results proved the long-term one-directed relationship between the corruption level and country brand parameters (International migrant stock, Exports of goods and services, Foreign direct investment). For the EU countries, (Latvia, Lithuania, Poland and Ukraine) country brand had a positive impact on the declining of the corruption level. At the same time, for Ukraine it was impossible to improve country brand without overcoming the corruption issues and providing the relevant reforms for that purpose. Noted, that findings were the same as in the other scientific investigations which focused on the same issues: the impact of corruption on the country's brand. Thus, the countries with a positive dynamic of economic development did not have a huge problem with corruption. The vice versa situation with poor countries which brand was not huge, and the corruption level was huge.

Author Contributions: Conceptualization, T. M. and K. T. and Y. H.; methodology, J. D.; software, J. D.; validation, K. T. and M. K. and Y. H.; formal analysis, T. M.; data curation, J. D.; writing-original draft preparation, T. M.; writing-review and editing, T. M. and K. T.; visualization, Y. H. and J. D.; supervision, K. T. and Y. H.; project administration, T. M.

\section{References}

Andéhn, M., Nordin, F., \& Nilsson, M. E. (2016). Facets of country image and brand equity: Revisiting the role of product categories in country-of-origin effect research. Journal of Consumer Behaviour, 15(3), 225-238.

Bilan, Y., Lyeonov, S., Lyulyov, O., \& Pimonenko, T. (2019). Brand management and macroeconomic stability of the country. [Zarządzanie marką i stabilność makroekonomiczna kraju] Polish Journal of Management Studies, 19(2), 61-74. doi:10.17512/pjms.2019.19.2.05 
Corruption Perceptions Index. (2019). Corruption Perceptions Index 2018: Score timeseries since 2012. Retrieved from: https://www.transparency.org/cpi2018

Fetscherin, M. (2010). The determinants and measurement of a country brand: the country brand strength index. International Marketing Review, 27(4), 466-479.

Granger, C. W. J. (1969). Investigating Causal Relations by Econometric Models and Cross-spectral Methods. Econometrica. 37 (3): 424-438. doi:10.2307/1912791

Hakimi, A., \& Hamdi, H. (2017). Does corruption limit FDI and economic growth? Evidence from MENA countries. International Journal of Emerging Markets, 12(3), 550-571.

Halkias, G., Davvetas, V., \& Diamantopoulos, A. (2016). The interplay between country stereotypes and perceived brand globalness/localness as drivers of brand preference. Journal of Business Research, 69(9), 3621-3628.

Herrero-Crespo, A., San Martín Gutiérrez, H., \& Garcia-Salmones, M. D. M. (2016). Influence of country image on country brand equity: Application to higher education services. International Marketing Review, 33(5), 691-714.

Johansen, Soren (1991). Estimation and Hypothesis Testing of Cointegration Vectors in Gaussian Vector Autoregressive Models. Econometrica. 59 (6), 1551-1580.

Levin, A., Lin, C-F., \& Chu, C-S. J. (2002). Unit root tests in panel data: asymptotic and finite-sample properties. Journal of Econometrics, 108(1), 1-24. doi:10.1016/S0304-4076(01)00098-7

Lin, C. P. \& Chuang, C. M. (2016). Corruption and brand value. International Marketing Review, 33(6), 758-780.

Lyulyov, O., Chygryn, O., and Pimonenko, T. (2018). National Brand as a Marketing Determinant of Macroeconomic Stability. Marketing and Management of Innovations, 3, 142-152. http://doi.org/10.21272/mmi.2018.3-12

Nwankwo, O. F. (2014). Impact of corruption on economic growth in Nigeria. Mediterranean Journal of Social Sciences, 5(6), 41-46.

Patrick, H. P. (2016). Corruption and its Impact on Good Governance in the Caribbean. Contemporary Security and Defense Issues in the Caribbean, 123

Ravi, S. P. (2015). Does corruption in a country affect the foreign direct investment? a study of rising economic super powers China and India. Open Journal of Social Sciences, 3(07), 99.

Sekrafi, H., \& Sghaier, A. (2018). Examining the relationship between corruption, economic growth, environmental degradation, and energy consumption: a panel analysis in MENA region. Journal of the Knowledge Economy, 9(3), 963-979.

Wang, Z., Zhang, B., \& Wang, B. (2018). The moderating role of corruption between economic growth and $\mathrm{CO} 2$ emissions: Evidence from BRICS economies. Energy, 148, 506-513.

World Bank (2019). World Development Indicators 2019, World Bank. Retrieved from : https://data.worldbank.org/indicator.

Тетяна Мілова, к.ю.н., доцент, Центральноукраїнський державний педагогічний університет імені Володимира Винниченка (Україна);

Катерина Трошкіна, к.ю.Н., Центральноукраїнський державний педагогічний університет імені Володимира Винниченка (Україна):

Євгеній Горлов, к.ю.н., Стипендіат урядової програми Республіки Польща для молодих академіків (Польща);

Ярослав Добковскі, Dr.Sc., профеесор, Вармінсько-Мазурськй університет в Ольштині (Польща).

Бренд країни та рівень корупції: коінтеграційний аналіз

Ця стаття узагальнюе аргументи та контраргументи в межах наукової дискусії щодо впливу корупції на бренд країни. Проаналізовано сучасні підходи до аналізу впливу рівня корупції на макроекономічні показники країни. Обгрунтовано, що підвищення рівня корупції в суспільстві вважається одним з найбільш значущих стримуючих факторів радикальних політичних та економічних змін, що відбуваються в країнах. Основною метою проведеного дослідження $\epsilon$ вивчення довгострокових та причинно-наслідкових зв'язків між рівнем контролю корупції та брендом країни. Об'єктом дослідження було обрано чотири європейські країни (Латвія, Литва, Польща та Україна), які проводили еволюційну політику реформування політичної та економічної системи після розпаду Радянського Союзу, що заохочувало практику подолання корупції. Період дослідження становить 2000-2018 рр. 3 метою вирішення поставленого завдання в роботі запропонований З етапний механізм оцінки довгострокових та причинно-наслідкових зв'язків між рівнем контролю корупції та основними компонентами бренду країн в основі якого покладено проведення тестів Augmented Dicker-Fuller та Granger casualty. Встановлено, що для України парні взаємозв'язки рівня контролю корупції та кількості мігрантів, контролю корупції та обсягом експорту, контролю корупції та обсягом зовнішніх інвестицій мають одно направлений характер впливу рівня корупції на складові рівня бренду країни. Результати проведеного дослідження свідчать, шо 51,73\%, 43,79\% та 66\% від загальних коливань мігрантів, експорту, та обсягу зовнішніх інвестицій залежать від змін рівня корупції в країні. Результати емпіричного аналізу засвідчили, що для країн Європейського Союзу (Польща, Литва та Латвія) саме бренд країни має позитивний вплив на зменшення рівня корупції. Обгрунтовано, що саме вибір конкретної моделі боротьби з рівнем корупції в даних країнах значно зумовив курс їх політичної трансформації, а також вплинув на темпи змін соціально-економічного розвитку.

Ключові слова: бренд, стейкхолдери, конкурентоспроможність, інвестори, корупція.

Manuscript received: 12.07.2019

(C) The author(s) 2019. This article is published with open access at Sumy State University. 